\title{
Implikasi Hukum Peraturan Pelayanan Hak Taggungan Secara Elektronik Terhadap Ppat Dan Kreditur Di Kota Yogyakarta
}

\section{Dhana Charina Ardhanary}

Magister Kenotariatan Fakultas Hukum Universitas Islam Indonesia Yogyakarta Indonesia Jln. Cik Di Tiro No. 1 Yogyakarta Indonesia dhanaacharina@gmail.com

Key Word:
Creditor; electronic
mortgage;
implication; PPAT

\begin{abstract}
This legal writing aims to examine the legal implications of implementing electronic mortgage service regulations for PPAT and creditors in the city of Yogyakarta. This type of research is normative with a statutory approach and a conceptual approach with qualitative analysis methods. The results of this study conclude that, first, the legal implications of the issuance of PM ATR/BPN No. 5 of 2020 on PPAT and Creditors are: (i) to creditors, they are obliged to submit applications for registration of Mortgage Rights directly through the electronic system and have the authority to print records of encumbrance of rights. Dependents to be attached to the certificate of Land Rights that are guaranteed, (ii) the PPAT need only to submit the APHT through the electronic system and guarantees the validity of the supporting documents contained in the statement sent via the electronic system. Second, regarding the application of Article 10 paragraph (3) of the Mortgage Law against PM ATR/BPN No. 5 of 2020 is that for electronic Mortgage services, it is not possible to use Land Rights that have not been registered as they have not been inputted into the system as in the HT-el system, one must have a land right in which there is a certificate number for that right. When there are Land Rights that have not been registered to be used as collateral for Mortgage Rights, they must be converted or registered in parallel.
\end{abstract}

\begin{tabular}{ll}
\hline Kata-kata Kunci: & Abstrak \\
\cline { 2 - 3 } $\begin{array}{l}\text { Hak Tanggungan } \\
\text { elektronik; }\end{array}$ & $\begin{array}{l}\text { Penulisan hukum ini bertujuan untuk mengkaji implikasi hukum penerapan } \\
\text { Implikasi; PPAT; }\end{array}$ \\
Kreditur & Kreditur di Kota Yogyakarta. Jenis penelitian ini bersifat normatif dengan \\
& pendekatan perundang-undangan dan pendekatan konseptual dengan \\
& metode analisis kualitatif. Dari hasil penelitian ini menyimpulkan, pertama, \\
& implikasi hukum dari diterbitkannya PM ATR/BPN No 5 Tahun 2020 \\
& terhadap PPAT dan Kreditur: (i) terhadap kreditur, berkewajiban untuk \\
& menyampaikan permohonan pendaftaran Hak Tanggungan langsung \\
& melalui sistem elektronik serta mempunyai kewenangan dalam mencetak \\
& catatan pembebanan hak tanggungan guna dilekatkan pada sertifikat Hak \\
& Atas Tanah yang dijaminkan, (ii) terhadap PPAT hanya menyampaikan \\
& APHT melalui sistem elektronik dan memberikan jaminan terhadap \\
& keabsahan dokumen-dokumen pendukung yang dimuat dalam surat \\
& pernyataan yang dikirim melaui sistem elektronik. Kedua, mengenai \\
& penerapan Pasal 10 ayat (3) Undang-Undang Hak Tanggungan terhadap PM \\
& ATR/BPN No 5 Tahun 2020, bahwa untuk layanan Hak Tanggungan secara \\
& elektronik tidak dimungkinkan untuk menggunakan Hak Atas Tanah yang \\
& belum didaftarkan, karena tidak masuk ke dalam sistem, dalam sistem HT- \\
& el harus mempunyai Hak Atas Tanah yang mana terdapat nomor sertifikat \\
& hak tersebut. Ketika terdapat Hak Atas Tanah yang belum di daftarkan akan \\
& digunakan sebagai jaminan Hak Tanggungan, maka harus dikonversikan \\
& atau didaftarkan secara pararel. \\
&
\end{tabular}




\section{Pendahuluan}

Seiring dengan kemajuan zaman, setiap orang yang berusaha selalu ingin meningkatkan usaha tersebut, namun ada kalanya dibatasi oleh kemampuan di bidang permodalan. ${ }^{1}$ Salah satu solusi untuk dapat menyelesaiakn masalah itu ialah dengan adanya Fasilitas Kredit, Fasilitas kredit ini akan sangat membantu bagi mereka. Untuk melindungi uang yang dikucurkan melalui kredit dari risiko kerugian, maka pihak perbankan membuat pagar pengamanan. Pagar pengamanan yang dibuat biasanya berupa jaminan yang harus disediakan debitur. Penyerahan jaminan utang oleh debitur kepada kreditur sebagai upaya meyakinkan kreditur agar memberikan pinjam fasilitas kredit (uang) kepada debitur dan jika debitur wanprestasi maka jaminannya tersebut akan dilelang untuk melunasi utang debitur. ${ }^{2}$

Lembaga jaminan oleh perbankan dianggap paling efektif dan aman adalah tanah dengan jaminan Hak Tanggungan. Hal ini didasarkan pada kemudahan dalam identifikasi objek Hak Tanggungan, jelas dan pasti eksekusinya serta mendahulukan pembayaran dari hasil pelelangan tanah kepada krediturnya. Pemanfaatan lembaga eksekusi Hak Tanggungan merupakan cara percepatan pelunasan piutang agar dana yang telah dikeluarkan oleh bank dapat segera dibayarkan dan dapat digunakan kembali oleh debitur lainnya. ${ }^{3}$ Menurut Undang-Undang Nomor 4 Tahun 1996 Pasal 1 angka 1, Hak Tanggungan adalah hak jaminan yang dibebankan pada hak atas tanah sebagaimana dimaksud dalam Undang-Undang Nomor 5 Tahun 1960 tentang Peraturan Dasar PokokPokok Agraria, berikut atau tidak berikut benda-benda lain yang merupakan satu kesatuan dengan tanah ini, untuk pelunasan utang tertentu, yang memberikan kedudukan yang diutamakan kepada kreditur tertentu terhadap kreditur-kreditur lain.

Untuk menjamin kepastian hukum, dalam Pasal 13 Undang-Undang Hak Tanggungan pemberian Hak Tanggungan harus didaftarkan pada kantor pertanahan dengan jangka waktu selambat-lambatnya tujuh hari kerja setelah penandatanganan Akta Pemberian Hak Tanggungan (APHT), dan PPAT wajib mengirimkan APHT yang bersangkutan dan warkah lain yang diperlukan kepada Kantor Pertanahan. Pada tanggal 8 Juli 2020, pemerintah melalui Menteri ATR/BPN menerbitkan "Peraturan Menteri Agraria dan Tata Ruang/Kepala Badan Pertanahan Nasional Republik Indonesia Nomor 5 Tahun 2020 Tentang Pelayanan Hak Tanggungan Terintegrasi Secara Elektronik".

Diharapkan dengan HT-el (Hak Tanggung Elektronik) ini akan mengurangi 40 persen antrian yang ada di loket Kantor Pertanahan, akan mengurangi potensi fraud, mengurangi warkah yang selama ini menumpuk di Kantor Pertanahan, dapat memberikan kepastian waktu dan juga kepastian biaya kepada masyarakat. ${ }^{4}$ Maka hlm. 17.

1 Thomas Suyatno dkk, Dasar-Dasar Perkeditan Edisi Empat, PT Gramedia Pustaka Utama, Jakarta, 2007,

${ }^{2}$ Ashibly, Hukum Jaminan, Unihaz, Bengkulu, 2018, hlm. 13

3 Anton Suyatno,Kepastian Hukum Dalam Penyelesaian Kredit Macet Melalui Eksekusi Jaminan Hak. Tanggungan Tanpa Proses Gugatan Pengadilan, Kencana, Jakarta, 2016, hlm. 8.

${ }^{4}$ https://www.propertynbank.com/hak-tanggungan-elektronik-berlaku-nasional-atr-hapus-caraconvensional/, "Hak Tangguungan Elektronik Berlaku Nasional ATR Hapus Cara Konvensional”, diakses pada 27 November 2020. 
dengan diberlakukan peraturan tersebut secara serentak pelayanan hak tanggungan secara konvensional ditutup.

Terdapat beberapa permasalahan setelah diterapkannya PM ATR/BPN No. 5 Tahun 2020 (sebelumnya PM ATR/BPN No 9 Tahun 2019), yakni terkait lahirnya hak tanggungan menjadi kabur dan tidak disebutkan dalam Peraturan tersebut. Adapun kendala yang dihadapi oleh PPAT dan Kreditur terkait keadaan darurat, yakni dalam Pasal 25 diatur bahwa dalam hal terjadi keadaan darurat di luar kendali manusia (force majeure) dan/atau keadaan tertentu yang menyebabkan Sistem HT-el terganggu dan hasil Pelayanan HT-el tidak dapat diterbitkan, maka permohonan Pelayanan HT-el dinyatakan batal. Menyebabkan sistem hak tanggungan terganggu dan hasil layanan tidak dapat diterbitkan sehingga menimbulkan kerugian pada kreditur, akibat dari kejadian tersebut mengakibatkan posisi kreditur menjadi kreditur konkuren karena dengan batalnya proses hak tanggungan tidak akan melahirkan Hak Prefernce. ${ }^{5}$ Selain itu Pasal 20 ayat (3) dan (4) Peraturan Menteri ATR/KBPN Nomor 5 Tahun 2020 mengatur bahwa (3) dalam hal terdapat dokumen yang dinyatakan palsu dan digunakan sebagai dasar penerbitan Sertipikat HT-el, maka pegawai Kantor Pertanahan tidak dapat dikenai pertanggungjawaban secara hukum. Dokumen yang dinyatakan palsu sebagaimana dimaksud pada ayat (3), sepenuhnya menjadi tanggungjawab pengirim dokumen baik pidana maupun perdata. Dan juga saat setelah APHT ditandatangani, para pihak, selanjutnya didaftarkan melalui sistem elektronik, ganguan server sering muncul saat PPAT mengupload dokumen Akta dan lainnya. Padahal PPAT hanya punya waktu 7 hari kerja setelah APHT ditandatangani untuk segera mendaftar dalam sistem tersebut. Dari Kreditor problem yang sering dihadapi karena belum terdaftar dan belum tervalidasi pada sistem layanan HT-el. ${ }^{6}$

Selanjutnya, mengenai objek pelayanan Hak Tanggungan Elektronik, PM ATR/BPN No. 5 Tahun 2020 dalam Pasal 6 ayat (2) menyebutkan bahwa Objek Hak Tanggungan yang dapat diproses dengan Pelayanan HT-el merupakan objek Hak Tanggungan sebagaimana diatur dalam peraturan perundang-undangan. Sedangkan pada PM ATR/BPN No. 5 Tahun 2020 tidak diatur mengenai objek Hak Tanggungan berupa Hak Atas Tanah yang belum didaftarkan dalam artian tidak ada layanan Hak Tanggungan elektronik untuk Hak Atas Tanah yang belum di daftarkan, hanya mengatur Hak Atas Tanah yang sudah di daftarkan, sehingga menyebabkan PM ATR/BPN No. 5 Tahun 2020 bertentangan dengan Pasal 10 (3) Undang-Undang Hak Tanggungan. Hal ini tentunya menjadi pertanyaan apabila Hak Atas Tanah belum didaftarkan apakah bisa diterapkan pada Pelayanan Hak Tanggungan Elektronik, karena di Indonesia masih ada tanah yang belum di daftarkan.

${ }^{5}$ Erich Kurniawan Widjaja, "Kedudukan Kreditor Pemegang Hak Tanggungan Dalam Hal Terjadi Force Majeure Dan/Atau Keadaan Tertentu Yang Menyebabkan Sistem Hak Tanggungan Elektronik Terganggu", Tesis, Universitas Airlangga, Surabaya, hlm. vi.

${ }^{6}$ Pandam Nurwulan, https://www.krjogja.com/angkringan/opini/hak-tanggungan-elektronik-berlakunasional-ppat-dan-kreditor-siapkah/, "Hak Tanggungan Elektronik Berlaku Nasional. PPAT dan Kreditor, Siapkah?”, diakses pada 28 November 2020. 


\section{Rumusan Masalah}

Permasalahan dalam penelitian ini dirumuskan sebagai berkut: pertama, bagaimana implikasi hukum PM ATR/BPN No 5 Tahun 2020 tentang Pelayanan Hak Tanggungan secara elektronik terhadap PPAT dan kreditur di Kota Yogyakarta? Kedua, apakah Pasal 10 ayat (3) Undang-Undang Hak Tanggungan dapat diterapkan pada pelayanan hak tanggungan secara elektronik?

\section{Tujuan Penelitian}

Tujuan penelitian ini adalah untuk mengkaji implikasi hukum penerapan peraturan pelayanan hak tanggungan secara elektronik terhadap PPAT dan Kreditur di Kota Yogyakarta serta permasalahan objek hak tanggungan berupa hak atas tanah yang belum di daftarkan terhadap peraturan pelayanan hak tanggungan elektronik.

\section{Metode Penelitian}

Penelitian ini men ggunakan penelitian normatif, yang didukung dengan keterangan yang diambil dari narasumber (PPAT, kreditur yang sudah melakukan pendaftaran hak tanggungan secara elektronik serta BPN). pendekatan yang digunakan dalam penelitian ini adalah pendekatan perundang-undangan (statute approach) dan pendekatan konseptual (conceptual approach). Data yang telah diperoleh dari kepustakaan dan undang-undang dianalisis secara dekriptif kualitatif.

\section{Hasil Penelitian dan Pembahasan}

\section{Implikasi Hukum Peraturan Pelayanan Hak Tanggungan Secara Elektronik Terhadap PPAT dan Kreditur}

Hak tanggungan merupakan perjanjian yang accesoir, artinya di samping adanya perjanjian pokok yang berwujud perjanjian pinjam-meminjam uang. Karena merupakan perjanjian yang accesoir, maka adanya hak tanggungan tergantung pada perjanjian pokok, dan akan hapus dengan hapusnya perjanjian pokok. ${ }^{7}$ Hak tanggungan merupakan hak jaminan atas tanah guna pelunasan utang yang kedudukan krediturnya diutamakan daripada kreditur lain. Kreditor hak tanggungan merupakan kreditor preference yaitu kreditor yang didahulukan dalam mendapatkan pelunasan utang dan berhak mengeksekusi secara langsung dengan lembaga parate eksekusi, sehingga apabila debitur cidera janji, kreditur sebagai pemegang hak tanggungan dapat menjual obyek hak tanggungan melalui penjualan dimuka umum atau pelelangan. ${ }^{8}$ Pentingnya pendaftaran hak tanggungan merupakan syarat mutlak untuk lahirnya hak tersebut, sehingga terpenuhinya asas publisitas yang mana membawa pengaruh penting terhadap perjanjian jaminan kebendaan yang dibuat oleh debitor dan kreditor. hlm. 182.

7 Titik Triwulan Tutik, Hukum Perdata Dalam Sistem Hukum Nasional, Prenadamedia Group, Jakarta, 2008,

8 IGA Gangga Santi Dewi dan Mira Novana, "Kebijakan Penjaminan Tanah Melalui Hak Tanggungan di Indonesia (Studi Penjaminan Hak Tanggungan Elektronik di Kabupaten Badung Provinsi Bali)", Jurnal Law Development \& Justice Review, No.1 Vol. 3 Mei 2020, hlm. 58 
Pemenuhan asas publisitas mengakibatkan bahwa perjanjian jaminan kebendaan tersebut tidak sekedar berlaku dan mengikat para pihak saja, tetapi juga akan mengikat pihak ketiga dan memberikan kepastian hukum kepada pihak-pihak yang berkepentingan, jika telah didaftarkan di kantor pertanahan sehingga terbuka dan diketahui oleh umum. ${ }^{9}$ Dengan diterbitkannya permen tersebut merupakan langkah maju Kementerian ATR-BPN dalam mempermudah masyarakat untuk mendapatkan pelayanan dari kementerian tersebut dengan memanfaatkan perkembangan teknologi ${ }^{10}$ dan juga diharapkan dengan HT-el ini akan mengurangi 40 persen antrean yang ada di loket kantor pertanahan, akan mengurangi potensi fraud, mengurangi warkah yang selama ini menumpuk di kantor pertanahan, dapat memberikan kepastian waktu dan juga kepastian biaya kepada masyarakat11, Penerbitan PM ATR/BPN NO. 5 Tahun 2020 pun berimplikasi pada perubahan dalam bentuk fisik sertifikat Hak Tanggungan dimana hanya selembar kertas sertipikat Hak Tanggungan serta catatan pembebanan Hak Tanggungan yang dilekatkan pada sertipikat hak atas tanah untuk menjadi satu kesatuan dengan sertipikat Hak Tanggungan. Dan dalam Sertifikat Hak Tanggungan tidak lagi dibubuhkan tandatangan kepala kantor pertanahan setempat, melainkan tanda barcode yang berisi seluruh informasi terkait Sertifikat Hak Tanggungan tersebut serta dapat digunakan mengecek hasil layanan dengan melakukan scan menggunakan aplikasi Sentuh Tanahku. Selain itu adanya perubahan mekanisme tugas PPAT dan pihak kreditur (Bank) dalam hal pendaftaran Hak Tanggungan. Adapun tahapan-tahapan yang dilakukan oleh PPAT dan Bank dalam pendaftaran Hak Tanggungan adalah sebagai berikut:

a. PPAT12:

1) Pihak kreditur/bank datang ke PPAT untuk dibuatkan APHT

2) Memvalidasi sertifikat/surat ukur objek jaminan Hak Tanggungan secara manual dan di cek ke sistem elektronik

3) Setelah seluruhnya valid, dibuatkan Akta Pembebanan Hak Tanggungan dan di tandatangani oleh PPAT tersebut

4) Akta tersebut di scan

5) kemudian di upload bersamaan dengan dokumen-dokumen lain, seperti KTP, sertifikat objek jaminan HT, PNBP, Kuasa bank, SKMHT (jika dasarnya dari SKMHT), kedalam sistem HT-el

6) mengisi identitas debitur, jika terdapat persetujuan di lengkapi juga identitas orang yang menyetujuinya

7) download surat pengantar akta dan diserahkan kepihak kreditur/Bank

b. Bank ${ }^{13}$ :

1. Pengguna HT-El mengajukan permohonan layanan melalui sistem layanan HT-El yang disediakan Kementerian

\footnotetext{
${ }_{9}$ Nadia Imanda, "Lahirnya Hak Tanggungan Menurut Peraturan Pemerintah Agraria Tentang Pelayanan Hak Tanggungan Terintegrasi Secara Elektronik”, Jurnal Notarie Vol. 3 No. 1, Februari 2020, hlm. 161

${ }^{10} \mathrm{http}: / /$ pusdiknas.com/workshop-nasional/ , Kebijakan dan Implementasi Hak. Tanggungan Terintegrasi Secara Elektronik Berdasakan Permen ATR No. 9 Tahun 2019, diakses pada 18 Desember 2020.

11 Pandam Nurwulan, Loc. Cit.

${ }^{12}$ Wawancaradengan PPAT Kota Yogyakarta Rio Kustianto Wironegoro di kantor Notaris dan PPAT Rio Kustianto Wironegoro, SH.,M.Hum pada 14 Desember 2020

${ }^{13}$ Wawancara via email bersama Didik Ahmad Nugroho selaku Penyelia Operasional Bank BPD DIY cabang Senopati, pada 16 Febuari 2021
} 
2. Pengguna HT-El bertanggung jawab terhadap keabsahan dan kebenaran data Dokumen Elektronik yang diajukan

3. Permohonan yang diterima oleh sistem akan diberikan tanda bukti pendaftaran permohonan

4. Debitor melakukan pembayaran biaya sesuai ketentuan melalui bank persepsi paling lambat 3 hari setelah tanggal pendaftaran permohonan

5. Pengguna wajib memantau proses permohonan dan pembayaran pada sistem HT-El

6. Bila pembayaran biaya pendaftaran tidak terkonfirmasi oleh sistem, maka pengguna melakukan konfirmasi secara langsung kepada Kantor Pertanahan atau Layanan Pengaduan serta mendokumentasi bukti konfirmasi yang dilakukan

7. Pengguna melakukan dokumentasi sertifikat HT dan Catatan HT pada SHM/SHGB.

Pendaftaran hak tanggungan elektronik atau HT-el, kreditur atau pegawai PPAT tidak perlu datang ke kantor pertanahan kabupaten karena dengan PM ATR/BPN No. 5 Tahun 2020 ada pemisahan antara perbuatan pendaftaran HT-el dengan perbuatan pembuatan penyampaian APHT. Penyampaian APHT kepada Kantor Pertanahan tetap menjadi tugas PPAT untuk menyampaikan akta yang dibuatnya sesuai batas waktu yang ditentukan. Penyampaian akta tersebut dapat dilakukan secara elektronik hal tersebut diatur dalam Pasal 10 Permen Agraria No. 9 Tahun 2019.

Permohonan pendaftaran HT-el menjadi kewajiban kreditur, sehingga apabila kreditur lalai tidak mendaftarkannya maka resiko dan akibat hukumnya menjadikan jaminan yang diberikan tersebut tidak memberikan hak-hak istimewa yang diberikan oleh UU Hak Tanggungan. PPAT dalam hal ini hanya perlu mengecek sertipikat ke kantor pertanahan, kegunaan checking ini bertujuan untuk mengetahui apakah benar letak tanah telah sesuai seperti yang ada dalam sertipikat dan lain sebagainya. Kreditur atau PPAT dapat mendaftar melalui website resmi dari Kementerian Agraria dan Tata Ruang Badan Petanahan Nasional yaitu melalui https:/ / mitra.atrbpn.go.id. ${ }^{14}$

\section{Penerapan Pasal 10 ayat (3) Undang-Undang Hak Tanggungan terhadap PM ART/BPN No. 5 Tahun 2020}

Dalam hal perbedaan pengaturan Pasal 10 ayat (3) Undang-Undang Hak Tanggungan dengan PM ATR/BPN No 5 Tahun 2020 terkait jaminan Hak Atas Tanah yang belum didaftarkan, dimana pada penjelasan Pasal 10 ayat (3) UUHT bahwa pembebanan Hak Tanggungan pada hak atas tanah itu dimungkinkan asalkan pemberiannya dilakukan bersamaan dengan permohonan pendaftaran hak atas tanah tersebut. Kemungkinan ini dimaksudkan untuk memberi kesempatan kepada pemegang hak atas tanah yang belum besertifikat untuk memperoleh kredit. Disamping itu, kemungkinan di atas dimaksudkan juga untuk mendorong pensertifikatan hak atas tanah

${ }^{14 N a i l u ~ V i n a ~ A m a l i a d k k, ~ " A n a l i s i s ~ K e t e n t u a n ~ H a k ~ T a n g g u n g a n ~ E l e k t r o n i k ~ P a d a ~ P e r a t u r a n ~ M e n t e r i ~}$ Agraria Dan Tata Ruang Nomor 9 Tahun 2019 tentang Pelayanan Hak Tanggungan”, Jurnal Ilmiah Pendidikan Pancasila Dan Kewarganegaraan, Volume 5, 29 Desember 2020, hlm. 336. 
pada umumnya. Dengan adanya ketentuan ini berarti bahwa penggunaan tanah yang bukti kepemilikannya berupa girik, petuk, dan lain-lain yang sejenis masih dimungkinkan sebagaia guna sebagaimana diatur dalam Undang-Undang Nomor 7 Tahun 1992 tentang Perbankan. Sedangkan pada peraturan PM ATR/BPN No. 5 Tahun 2020 Pasal 15 hanya mengatur Hak Atas Tanah Yang sudah bersertifikat saja. Di Kota Yogyakarta sendiri sudah tidak ada lagi tanah lama karena pengadministrasian di BPN sudah tertib. Ketika terdapat Hak Atas Tanah yang belum di daftarkan digunakan sebagai jaminan Hak Tanggungan, maka harus dikonversikan atau didaftarkan secara pararel, maksudnya Hak Atas Tanah lama terlebih dahulu harus didaftarkan sesuai dengan prosedur pendaftaran tanah seperti biasa. Setelah sertifikat Hak Atas Tanah terbit, tujuh hari dari penerbitan barulah bisa dipasang untuk jaminan Hak Atas Tanah. Di BPN sendiri terdapat program strategis nasional yang bernama PTSL (Pendaftaran Tanah SistematisLengkap) yang dahulu disebut prona, dimana seluruh tanah di Indonesia harus sudah bersertifikat. Untuk Kota Yogyakarta tahun ini sudah tidak ada program tersebut karena sudah banyak yang bersertifikat. Selain itu layanan di BPN ada 2 yakni:

a. Layanan pendaftaran pertama kali ditujukan untuk tanah yang belum bersertifikat seperti girik, petuk, letter $C$ yang nantinya akan diukur kembali dan di umumkan selama 2 bulan, ketika tidak ada sanggahan maka akan diterbitkan sertifikat. Disamping itu layanan pendaftaran pertama kali ditujukan untuk tanah negara yang belum mempunyai hak, namun untuk Daerah Istimewa Yogyakarta sendiri tidak ada tanah negara karena semuanya tanah hak Kraton Yogyakarta, sehingga untuk DIY jika ingin mendaftar sebagai Hak Atas Tanah harus izin terlebih dahulu kepada Kraton Yogyakarta.

b. Layanan pemeliharaan data seperti jual beli, roya, hibah, waris dan lain-lain kecuali blokir.

Berdasarkan wawancara dengan Nur Wiyandari selaku Kepala Badan Pertanahan Nasional Kota Yogyakarta, bahwa memang untuk layanan Hak Tanggungan secara Elektronik tidak dimungkinkan untuk menggunakan Hak Atas Tanah yang belum didaftarkan, karena tidak masuk ke dalam sistem, dalam sistem HT-el harus mempunyai Hak Atas Tanah yang mana terdapat nomor sertifikat hak tersebut. Menurut St. Remy Sjahdeini, ketentuan Pasal 10 ayat (3) itu merupakan keterkaitan dengan ketentuan Pasal 8 UU Nomor 7 Tahun 1992 tentang perbankan yang didalam penjelasan pasal tersebut dikemukakan bahwa tanah girik, petuk, dan lain-lain yang sejenis dapat digunakan sebagai agunan. Menelaah dengan cermat ketentuan Pasal 10 ayat (3) UUHT dan penjelasannya, serta ketentuan Pasal 8 UU Nomor 7 Tahun 1992 tentang Perbankan, maka menurut Supriadi pada tataran hukum formal dimungkinkan untuk menjadikan bukti girik, petuk, dan sejenisnya dijadikan jaminan utang. Hal inilah yang menjadi permasalahan, sebab dalam kenyataan bank akan menerima tanah yang akan dijadikan agunan jika tanah tersebut telah memiliki sertifikatnya. Karena girik, petuk dan sejenisnya bukanlah merupakan tanda bukti hak kepemilikan atas tanah, tetapi sekedar merupakan tanda bukti pembayaran pajak atas tanah itu harus dibayar pajaknya oleh mereka yang menggunakan tanah tersebut, sementara itu banyak masyarakat di desa 
yang memiliki tanah dengan hanya mengandalkan tanda bukti girik dan petuk. ${ }^{15}$ Dalam pembebanan Hak Tanggungan dari objek tanah yang belum terdaftar untuk dijadikan jaminan utang debitor kepada bank (kreditor) pada tataran normatif dapat dilakukan bersamaan untuk mengajukan pendaftaran tanah pertama kali ke Kantor Pertanahan dan dimungkinkan adanya kesempatan kepada pemegang hak lama tersebut, hal ini sesuai aturan dalam Pasal 10 ayat (3) UUHT. Tetapi dalam konteks penerapannya hal ini masih menemui beberapa kendala, yaitu pertama, belum adanya kepastian hukum akan data fisik dan data yuridis tanah tersebut, hal ini akan berpotensi adanya keberatan bahkan gugatan dari pihak ketiga, sehingga secara mayoritas kreditor dalam hal ini pihak bank menolak untuk di bebankan Hak Tanggungan. Kedua, adanya prinsip kehati-hatian (prudential principal) dari pihak bank. ${ }^{16}$ Menurut Abdurrahman, dengan berlakunya Undang-Undang Hak Tanggungan maka kemungkinan untuk menjadikan tanah-tanah hak adat sebagai agunan hanya tinggal sejarah hukum saja. Karena dalam penjelasan Pasal 10 ayat (3) menunjukkan bagaimana caranya untuk meningkatkan pemberian agunan tersebut menjadi hak tanggungan. Undang-Undang bukan saja bermaksud memperlancar arus perkreditan, yang berarti juga lebih menekankan aspek kepastian hukum, yaitu keharusan untuk daftara dan dengan sendirinya untuk lebih mendorong kegiatan pendaftaran tanah di Indonesia. ${ }^{17}$ Dalam pemberian kredit, dimana salah satunya adalah prinsip collateral (jaminan). Jaminan disini berarti kekayaan yang dapat dikaitkan sebagai jaminan guna kepastian pelunasan dikemudian hari jika penerima kredit tidak melunasi hutangnya. Hal ini sejalan dengan Pasal 8 Undang-Undang Perbankan nomor 10 Tahun 1998 yang menegaskan bahwa dalam memberikan kredit atau pembiayaan berdasarkan Prinsip Syariah, Bank Umum wajib mempunyai keyakinan berdasarkan analisis yang mendalam atas iktikad dan kemampuan serta kesanggupan Nasabah Debitur untuk melunasi utangnya atau mmengembalikan pembiayaan dimaksud sesuai dengan yang diperjanjikan. ${ }^{18}$

\section{Penutup}

Berdasarkan uraian dan analisis di atas, disimpulkan, pertama, implikasi hukum dengan diterbitkannya PM ATR/BPN No. 5 Tahun 2020 terhadap PPAT dan Kreditur adalah, terhadap kreditur terdapat perubahan pada mekanisme tugas kreditur dimana kreditur mempunyai kewajiban untuk menyampaikan permohonan pendaftaran Hak Tanggungan langsung melalui sistem elektronik serta mempunyai kewenangan dalam mencetak catatan pembebanan Hak Tanggungan guna di lekatkan pada sertifikat Hak Atas Tanah yang dijaminkan. Selain itu penerbitan PM ATR/BPN No 5 Tahun 2020 berimplikasi juga terhadap ketepatan waktu pendaftaran yakni tujuh hari sehingga dapat memperlancar pemberian kredit kepada debitur, kemudahan manajemen asest (tidak

\footnotetext{
${ }^{15}$ Supriadi, Op. Cit., hlm. 194

16 Abdul Kholiq Imron, Pembebanan Hak Tanggungan Terbadap Objek Tanah Yang Belum Terdaftar Bersamaan Permohonan Pendaftaran Tanah Pertama Kali, Jurnal Repertorium Volume Iv No. 2 Juli-Desember 2017, hlm. 13.

17 Abdurrahman dalam Rahmadi Usman, Hukum jaminan keperdataan cetakan Kedua, Sinar Grafika, Jakarta, 2009, hlm. 407.

${ }^{18}$ Levy Mariam Darus Badrulzaman. Perjanjian Kredit Bank, PT Citra Aditya Bakti, Bandung, 1991, hlm. 59.
} 
perlu memindai sertipikat Hak Tanggungan) karena sudah tercatat pada sistem elektronik serta reporting dan monitoring jumlah dan nilai Hak Tanggungan di seluruh cabang. Terhadap PPAT sendiri dalam hal mekanisme penyampaian APHT terdapat perubahan setelah diberlakukannya PM ATR/BPN No. 5 Tahun 2020 yaitu, pada saat pendaftaran Hak Tanggungan secara manual dimana PPAT harus datang langsung kekantor BPN dan mengurus keseluruhan sampai diterbitkannya sertifikat Hak Tanggungan, kini tugas PPAT hanya sampai menyampaikan APHT melalui sistem elektronik dan memberikan jaminan terhadap keabsahan dokumen-dokumen pendukung yang dimuat dalam sebuat surat pernyataan yang dikirim melaui sistem elektronik.

Kedua, mengenai penerapan Pasal 10 ayat (3) Undang-Undang Hak Tanggungan terhadap PM ATR/BPN No. 5 Tahun 2020, bahwa untuk layanan Hak Tanggungan secara Elektronik tidak dimungkinkan untuk menggunakan Hak Atas Tanah yang belum didaftarkan, dalam sistem HT-el harus mempunyai Hak Atas Tanah yang mana terdapat nomor sertifikat hak tersebut. Ketika terdapat Hak Atas Tanah yang belum di daftarkanakan digunakan sebagai jaminan Hak Tanggungan, maka harus dikonversikan atau didaftarkan secara pararel, maksudnya Hak Atas Tanah lama terlebih dahulu harus di daftarkan sesuai dengan prosedur pendaftaran tanah seperti biasa. Setelah sertifikat Hak Atas Tanah terbit, tujuh hari dari penerbitan barulah bisa dipasang untuk jaminan Hak Atas Tanah. Selain itu mempunyai resiko yang sangat besar dibandingkan dengan Hak Atas Tanah yang sudah disertifikatkan karena masih ada beberapa kemungkinan atau masih dalam bentuk proses konversi yang memakan waktu lama sehingga menyulitkan untuk PPAT, karena dari objek jaminanya belum pasti. Pihak bank pun tidak bisa memberikan kredit dengan jaminan hak tanggungan yang objeknya belum bersertifikat karena pihak bank sendiri mempunyai regulasi terhadap pengajuan kredit. Hal ini sesuai dengan prinsip kehati-hatian Bank dalam pemberian kredit, dimana salah satunya adalah prinsi $p$ collateral (jaminan). Jaminan disini berarti kekayaan yang dapat dikaitkan sebagai jaminan guna kepastian pelunasan dikemudian hari jika penerima kredit tidak melunasi hutangnya.

\section{Daftar Pustaka}

\section{Buku}

Anton, Suyatno, Kepastian Hukum Dalam Penyelesaian Kredit Macet Melalui Eksekusi Jaminan Hak Tanggungan Tanpa Proses Gugatan Pengadilan, Kencana, Jakarta, 2016.

Ashibly, Hukum Jaminan, Unihaz, Bengkulu, 2018.

Levy, Mariam, Perjanjian Kredit Bank, PT Citra Aditya Bakti, Bandung, 1991.

Rahmadi, Usman, Hukum Jaminan Keperdataan, cetakan Kedua, Sinar Grafika, Jakarta, 2009.Supriadi, Hukum Agraria, SinarGrafika, Jakarta, 2008.

Thomas, Suyatno, dkk, Dasar-Dasar Perkreditan Edisi Empat, PT Gramedia Pustaka Utama, Jakarta, 2007.

Triwulan Tutik, Titik, Hukum Perdata Dalam Sistem Hukum Nasional, Prenadamedia Group, Jakarta, 2008. 


\section{Hasil Penelitian}

Erich Kurniawan Widjaja, “Kedudukan Kreditor Pemegang Hak Tanggungan Dalam Hal Terjadi Force Majeure dan/atau Keadaan Tertentu Yang Menyebabkan Sistem Hak Tanggungan Elektronik Terganggu", Tesis, Universitas Airlangga, Surabaya.

\section{Jurnal}

Abdul Kholiq Imron, "Pembebanan Hak Tanggungan Terhadap Objek Tanah Yang Belum Terdaftar Bersamaan Permohonan Pendaftaran Tanah Pertama Kali", Jurnal Repertorium, Volume IV, No. 2, Juli-Desember 2017.

IGA Gangga Santi Dewi dan Mira Novana, “Kebijakan Penjaminan Tanah Melalui Hak Tanggungan di Indonesia (Studi Penjaminan Hak Tanggungan Elektronik di Kabupaten Badung Provinsi Bali)", Jurnal Law, Development \& Justice Review, No. 1 Vol. 3, Mei 2020.

Nadia Imanda, "Lahirnya Hak Tanggungan Menurut Peraturan Pemerintah AgrariaTentang Pelayanan Hak Tanggungan Terintegrasi Secara Elektronik", Jurnal Notarie Vol. 3, No. 1, Februari 2020.

Nailu Vina Amaliadkk, "Analisis Ketentuan Hak Tanggungan Elektronik Pada Peraturan Menteri Agraria Dan Tata Ruang Nomor 9 Tahun 2019 Tentang Pelayanan Hak Tanggungan", Jurnal Ilmiah Pendidikan Pancasila Dan Kewarganegaraan, Volume 5, 29 Desember 2020.

\section{Internet}

http://pusdiknas.com/workshop-nasional/, Kebijakan Dan Implementasi Hak Tanggungan Terintegrasi Secara Elektronik Berdasakan Permen Atr No. 9 Tahun 2019, diakses pada 18 Desember 2020.

https://www.propertynbank.com/hak-tanggungan-elektronik-berlaku-nasional-atrhapus-cara-convensional/, "Hak Tangguungan Elektronik Berlaku Nasional ATR Hapus Cara Konvensional", diakses pada 27 November 2020.

Pandam Nurwulan, https://www.krjogja.com/angkringan/opini/hak-tanggunganelektronik-berlaku-nasional-ppat-dan-kreditor-siapkah/, "Hak Tanggungan Elektronik Berlaku Nasional. PPAT dan Kreditor, Siapkah?", di akses pada 28 November 2020. 